\title{
Microclimate Energy Considerations in Building Design for Arid Regions
}

\author{
A. A. Alaskary*, A. M. Hasson**†, M. J. Jweeg**and M. L. Al-Waily*** \\ *Institute for Urban and Regional Planning, University of Baghdad, Baghdad, Iraq \\ **Technical Engineering, AlFarahidi University, Baghdad, Iraq \\ $* * *$ Department of Mechanical Engineering, Faculty of Engineering, University of Kufa, Kufa, Iraq \\ $\nmid$ Corresponding author: A. M. Hasson; am.hasson2@gmail.com
}

Nat. Env. \& Poll. Tech.

Website: www.neptjournal.com

Received: 31-08-2019

Revised: 01-10-2019

Accepted: 07-11-2019

Key Words:

Albedo

Climatic factors

Cooling \& heating degrees

Heating coefficient

\begin{abstract}
Climate is one of the main parameters that can influence building designs in Iraq. Analysis and assessment of microclimatological data can aid urban architects and engineers to optimize human comfort through environmentally sustainable practices. The results indicated that the long-term measurements of total solar insolation and ambient temperatures have increased by $2.9 \%$ and $6.5 \%$ respectively. Albedo resulted in good correlation with heating coefficients and temperature of $R^{2}=$ 0.89 and 0.63 respectively. Annual cooling degree days and heating degree days have reduced, while annual mean ambient temperatures and annual solar radiation have increased.
\end{abstract}

\section{INTRODUCTION}

Climate change has become one of the central issues of international concern (Al-Maamary et al. 2017, Butera 2014). Its impact may lead to drought, dust storms, floods and other events that will have serious effects on the sustainability of communities and their development (Osman et al. 2014, Zakaria et al. 2013). Sustainable building designers must take into account climatic factors such as temperature, detrimental weather phenomena, weather forecast, relative humidity, wind direction and speed, rainfall, soil temperature and sunshine (Zareaian \& Zadeh 2013). Sustainable design involves promoting environmental quality by minimising the adverse impact on the natural environment and buildings (Waro \& Mwasha 2013). It involves complex interactions among environmental, economic and social parameters in which it must be analysed and treated by the various stakeholders involved (Nste et al. 2017). The majority of construction designs adopted in Iraq leaves the buildings exposed to solar radiation (Rashid 2014).

A large percentage of Iraqi households use cooling equipment and mechanical air-conditioning. However, the challenge arises with a lack of electrical power and the unaffordability of privately-owned electrical generators (Roaf $\&$ Bairstow 2008).

Hence, minimal mechanical air-conditioning is needed for sustainable building designs. Climate data play an important role in setting sustainable construction and building standards, especially regarding renewable energy input and potential. Based on the severe climate conditions found in Iraq, sustainable building is essential to face the challenge of climate change issues (Al-Waeli et al. 2017, Al-Waeely et al. 2014).

Renewable energies are important tools to support social and environmental energy sustainability (Langston \& Ding 2001). Climatological information is required to understand how to construct sustainable buildings, and assess their energy efficiency, suitable for human comfort (Rashid 2014).

Hui \& Cheung (1997) and Lam (1995) have indicated that technical innovation is needed to optimize building design for climate change, especially for severe hot summers. It is necessary to design sustainable buildings with less cooling systems and equipment, to overcome the heat flow from hot southern winds during summer months (Hasson et al. 2013). To assess the risk level of climate change and allow for its inherent properties and weather, data limitations must be understood and analysed (Jaramillo-Nieves \& Del-Río 2010, Rashid 2014). Long-term data plays an important role in solar energy input annual assessments.

The main objective of this research is to investigate the influence of heat energy on building design in the Iraqi construction industry by analysing the environmental changes experienced over 16 years in the Baghdad region. This can 
support designers in understanding the development of the local climate when designing sustainable buildings. Many factors such as wind direction and pattern, community population and distribution and social matters are not investigated in this study (Lam 1995).

\section{MATERIALS AND METHODS}

\section{Data Collection}

Microclimatological parameters, including total solar radiation (specifically incoming and outgoing radiation) and air temperatures, have been provided by the Iraqi Meteorological Service. In this study, the degree-day values in relation to the mean temperature of $26.9^{\circ} \mathrm{C}$ for the region are used for the last 10 years (2007-2017).

Albedo, cooling and heating degrees and correlation analysis are calculated based on the collected data of solar radiation and temperatures for the Baghdad region only (Al-Waeely et al. 2014, Huld et al. 2018). The relationship between roof albedo and the temperature is performed by analysing diurnal variant values of building roof albedo and roof temperature.

\section{Study Area}

Iraq is a country located in southwest Asia. It covers an area of $437,072 \mathrm{~km}^{2}$ with a population of $38,988,704$ million (Huld et al. 2018, USAID 2010). Iraq has three main climate regions: arid desert, semi-arid steppe and moist mountainous. The desert region is extremely arid and hot, with average diurnal temperatures in the summer season ranging from $25^{\circ} \mathrm{C}-43^{\circ} \mathrm{C}$ and falling to $4^{\circ} \mathrm{C}-17^{\circ} \mathrm{C}$ in the winter season (Hasson et al. 2017, Encyclopedia 2009). The steppe region is also hot, with average diurnal temperatures ranging from $26^{\circ} \mathrm{C}-46^{\circ} \mathrm{C}$ in the summer season and falling to $5^{\circ} \mathrm{C}-18^{\circ} \mathrm{C}$ in the winter season (Hasson et al. 2013, Cofaigh et al. 1996). Finally, in the mountain region, the climate is considered to be cooler and wetter than the steppe region. The diurnal temperature at summer can range from $27^{\circ} \mathrm{C}-44^{\circ} \mathrm{C}$ while in winter it can range from $4^{\circ} \mathrm{C}-15^{\circ} \mathrm{C}$ (ESA 2017, Encyclopedia 2009, USAID 2010).

The Iraqi climate is characterized as arid region hot and dry most of the year (USAID 2010). In summer the highest temperatures occur in June, July and August, which can range between $43^{\circ} \mathrm{C}-53^{\circ} \mathrm{C}$ (Encyclopedia 2009, Fanack 2018), while in winter the temperature ranges from $1^{\circ} \mathrm{C}-8^{\circ} \mathrm{C}$. The annual rainfall at the desert region can reach $200 \mathrm{~mm}$, while it ranges between $200-400 \mathrm{~mm}$ within the steppe region from November to April to about $400-1000 \mathrm{~mm}$ or more in the mountain region (Omer 2011, King et al. 2003). The impact of the south/south-easterly Sharqi (Eastern) and the north/ north-westerly Shamal (Northern) winds leads to extreme dust storms which occur in summer and autumn (Muir 2009, Al-Ansari et al. 2013).

\section{RESULTS AND DISCUSSION}

Based on the scientific research into the impact of climate change, there is a demand for data on the various microclimatic parameters such as air temperature, relative humidity, wind speed and direction, solar radiation, and orange dust, particularly for the Baghdad region, as information to support urban planners and engineers (King et al. 2003). This essential information enables designers to compare the design implications of these climatic relationships.

Results show a noticeable variation in each month and season at low solar elevations (solar altitude less than $30^{\circ} \mathrm{C}$ ). Fig. 1 represents the global solar radiation to ambient temperature ratio during the year.

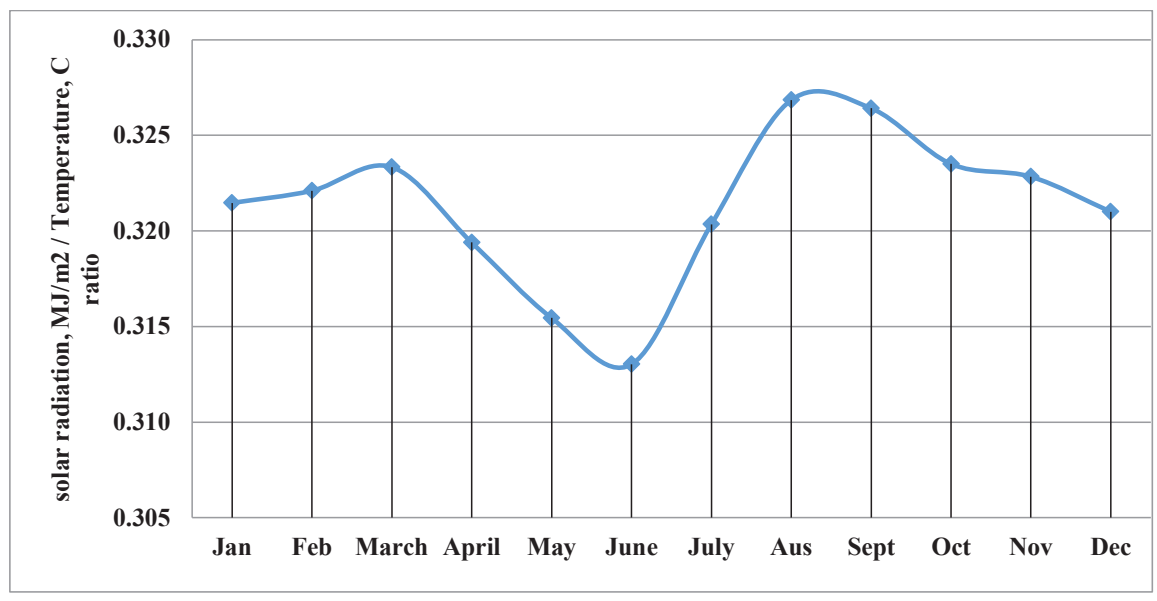

Fig. 1: Monthly average of daily ratios of global solar radiation and temperature. 
The measured data of ambient temperature, AT and actual sunshine duration, ASD, total solar radiation, Rs and wind speed WS relationships are shown in Fig. 2. There is a linear relation between the values. The equations were formed with a good confidant of correction coefficient (Fig. 2a, b and c and Table 1).

Screening of Fig. 3 and Table 1 shows correlations in the slope of the regressions, suggesting that there will be outcomes as a result of these climatic factors. Thus, the influence that sunshine duration, solar radiation and wind speed have on ambient temperature can have consequences such as the presence of possible dust storms and overheat.

Fig. 3 shows that the annual average of daily ambient temperature means for the Baghdad region over the past 10 years was increased by a percentage of 7.9 while the level of degree-days was reduced by $10.7 \%$.

Also, it has been found by analysing the annual heating and cooling degree-days over the study period (2008-2017) by taking into consideration a temperature of $26.6^{\circ} \mathrm{C}$ as a reference, that the Baghdad region has heated up as specified by the growth of cooling days and a lessening of heating days. This has important implications for urban climate and energy. The degree-day technique is used to estimate heat utilization in the early phase of thermal design (Yang \& Lu 2004, Chen et al. 2001).

To assess the difference of the long-term value of temperatures in the Baghdad region, a degree-day set for the study period has been established, as shown in Fig. 3.

\section{Albedo}

Albedo is a ratio of the irradiance absorbed to the irradiance reflected of a surface (Al-Ansari et al. 2014). Albedo plays an important role when determining climate change and energy budgets (Al-Ansari 2013). Albedo values typically range from $10 \%$ to $50 \%$ (Bonafoni et al. 2017). It can be increased up to $60 \%$, particularly on industrial and residential building roofs. For a given surface under the sun, albedo can be found in Fig. 5 and using the following equation (Schaaf et al. 2009, Bretz et al. 1998):

$$
(1-\alpha) \mathrm{I}=\varepsilon \sigma\left(\mathrm{T}^{4} \mathrm{~s}-\mathrm{T}^{4} \mathrm{sky}\right)+\mathrm{hc}(\mathrm{Ts}-\mathrm{Ta})
$$

Surface temperature has a close relation with surface albedo (Akbari et al. 2009, Zhang et al. 2005). Previous studies indicate that surface temperature and albedo are intimately related in high-latitude regions (Li \& Xiao 2007). However, few studies have focused on the quantification of surface temperature to surface albedo relationship.

Albedo plays an increasingly significant role in the summer season. This has happened in accordance with low solar altitude. Any change in solar angle combined with the influence of surface characteristics such as colour and type of the materials, can influence albedo values. High values of albedo denote a large amount of the incoming solar energy

Table 1: The expansion coefficient in AT $=\mathrm{a} 1+\mathrm{bx}$ equation the correlation coefficient $\left(\mathrm{R}^{2}\right)$.

\begin{tabular}{|llll|}
\hline Ambient temperatures & Intercept (a) & Slope (b) & $\mathrm{R}^{2}$ \\
\hline Wind Speed, $\mathrm{m} / \mathrm{s}$ & -5.94 & 37.70 & 0.67 \\
Total solar radiation, $\mathrm{MJm}^{-2} \mathrm{Rs}$ & 2.71 & -1.80 & 0.78 \\
Actual sunshine duration, hr ASD & 4.92 & 41.79 & 0.79 \\
\hline
\end{tabular}

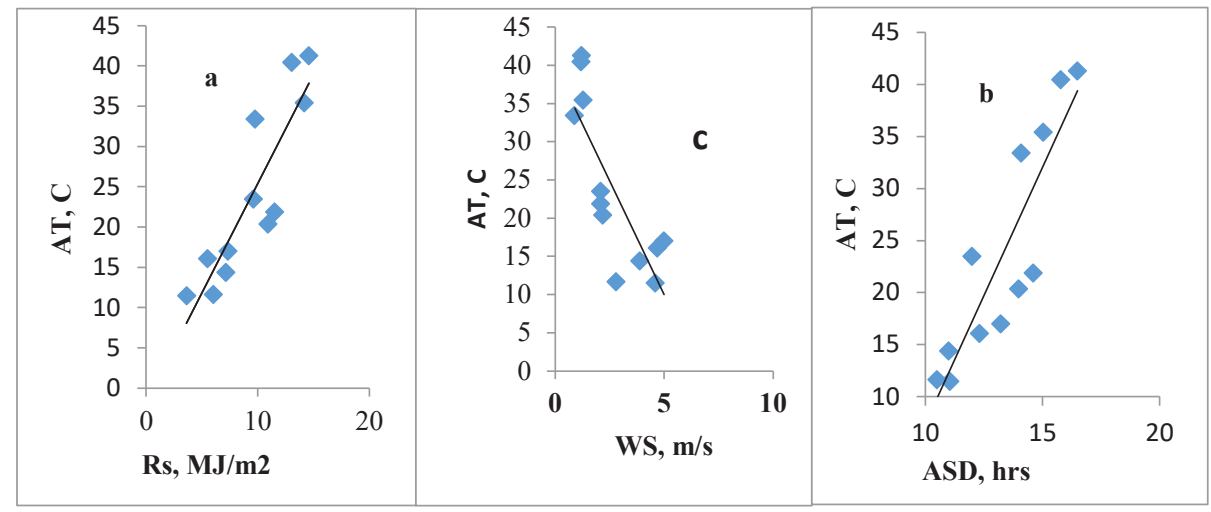

Fig. 2: Relationships between the annual average, monthly mean of ambient temperature and solar radiation (a), actual sunshine duration (b) and wind speed (c). 
and solar radiation is being reflected by the surface.

Finally, when using the relationship of albedo to temperature $(\alpha / \mathrm{T})$, a noticeable diurnal variation in each month was found. However, during low solar elevations (solar altitude less than $30^{\circ}$ ) there is a strong correlation between temperature and albedo $\left(\mathrm{R}^{2}=0.90\right)$ as illustrated in Fig. 5.

\section{Heating Coefficient (B)}

The heating coefficient is shown between materials of the building surface and the atmosphere in Fig 6.

The statistical relationship between albedo and heating coefficient parameters has good correlation confidence listed in Fig. 7, with $\mathrm{R}^{2}$ value of 0.63 .

\section{Night-Time Net Radiation, NTNR}

NTNR is the energy radiation emitted during the night hours, which has a significant effect on the proportion of the daytime net radiation, DTNR.
At night time the longwave radiation values have varied between -0.37 and $1.73 \mathrm{MJ} / \mathrm{m}^{2}$ which points out that the monthly variation in the value of nocturnal net radiation, NNR, was slightly different.

Fig. 8 shows the monthly average of long-wave net solar radiation. After sunset high values of negative net radiation occurred, they then decreased progressively, as the building roof ambient temperature decreased during the night hours, running to its minimal at sunrise. The roof (or the surface environment) was affecting long-wave net radiation.

Thus, the outward longwave radiation, which forms the factor NTNR, remains continuously throughout each month of the recorded period.

Construction materials are the crucial factor in meeting human comfort requirements while keeping sustainable economics to a maximum. Building design must consider climatic conditions, human comfort, expansion potential, environment and equipment maintainability.

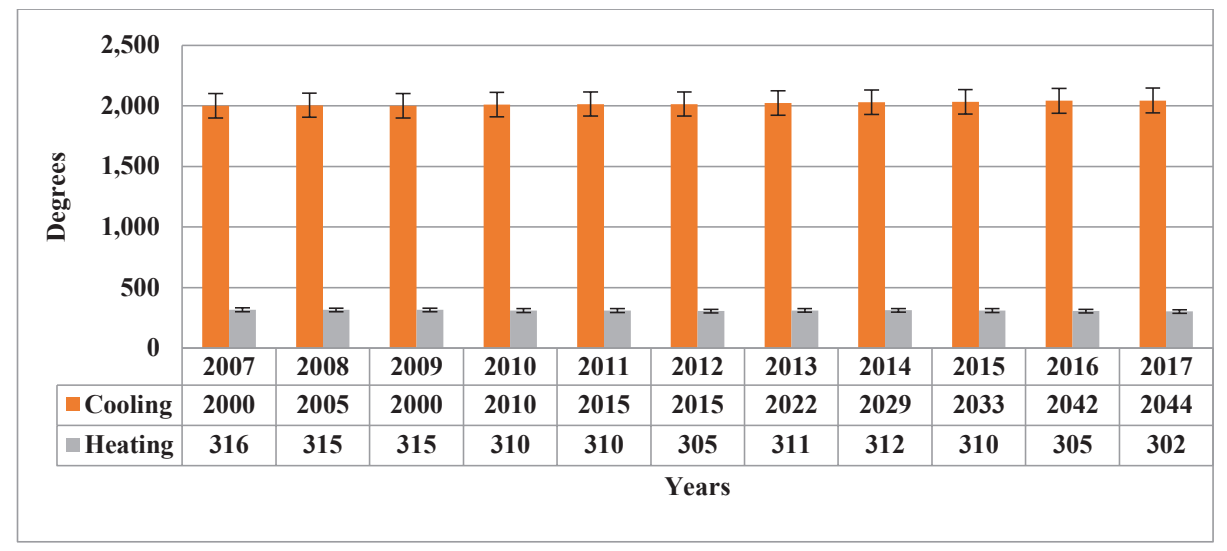

Fig. 3: Annual average of monthly heating and cooling degree-days.

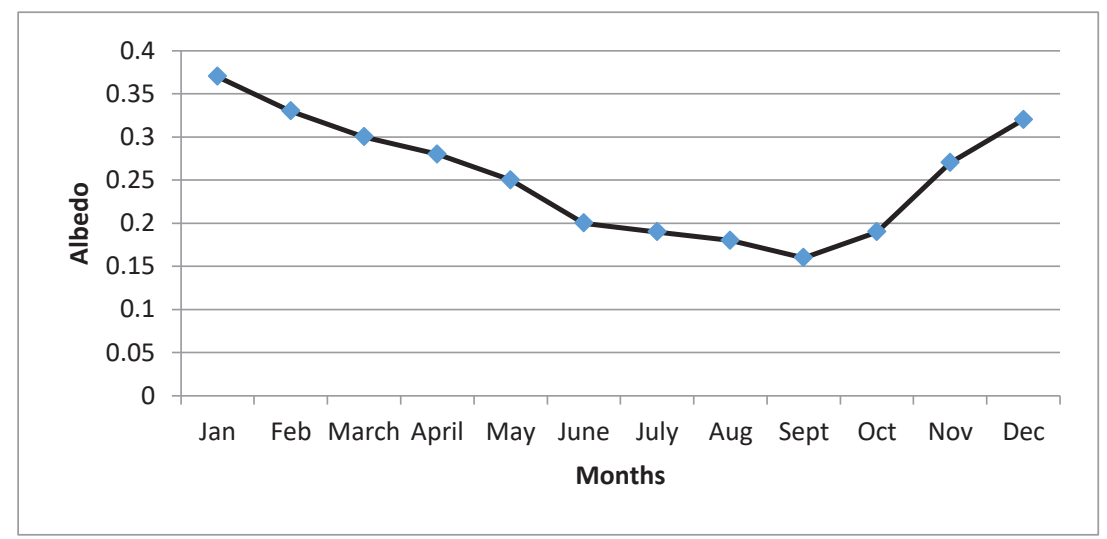

Fig. 4: Daily mean for monthly average albedo values. 


\section{Design Recommendation}

Based on the potential influence of climatic factors on the building issues discussed, we recommend as follows: For architectural enhancement, fixtures such as external cladding, which can make the construction process more efficient while improving the visible impact of the project. The fundamental requirement for the design of sustainable buildings is that the buildings run at minimum cost and comply with a severe environment. Parameters such as building orientation, shading, and materials appropriate for the climatic conditions of Baghdad must be factored in (Pike 1994, Torrance 1991).

Due to power shortages for mechanical air conditioning, designers have the challenge to fit replacements for sustainable buildings based on the tenants' energy requirements and climatic conditions. A direct substitute is available plant materials. The plant colour is relevant to sunlight density and duration.

\section{Ventilation}

Based on the severe climate especially during summer months, standards for ventilation and thermal comfort for sustainable residential and commercial buildings are needed. Traditional designs forming the majority of urban residential housing and older commercial buildings in the Baghdad region have had long lives are useful for long-time measurements. When urban engineers design sustainable buildings that account for the possibility of future climatic conditions, this will not only protect the wellbeing of occupants but could also produce economic benefits in the form of green building and longer building lives (Chen et al. 2001, Prelgauskas 2003).

Fortunately, building designers are good at incorporating these natural forces into their style and finding out the likely design solutions that produce sensible conclusions (Chapin et al. 1966, Prelgauskas 2003, Cofaigh et al. 1996).

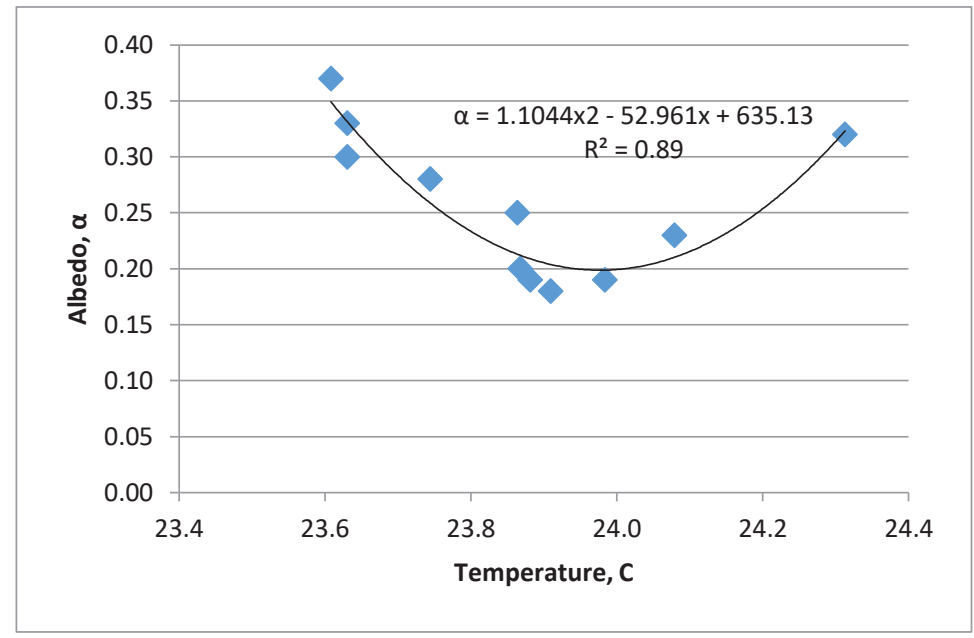

Fig. 5: Theoretical variation in temperature for values of albedo relationship at noon on the third day of the month.

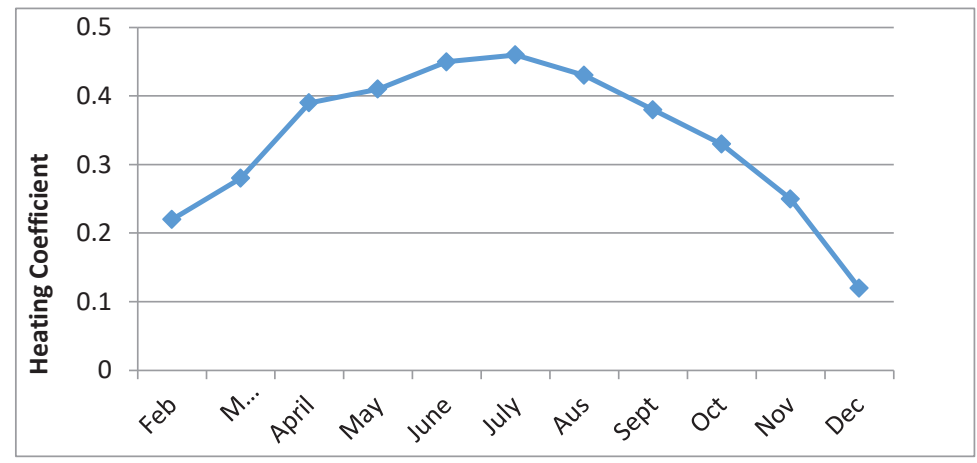

Fig. 6: Annual average of the monthly range of heating coefficients. 


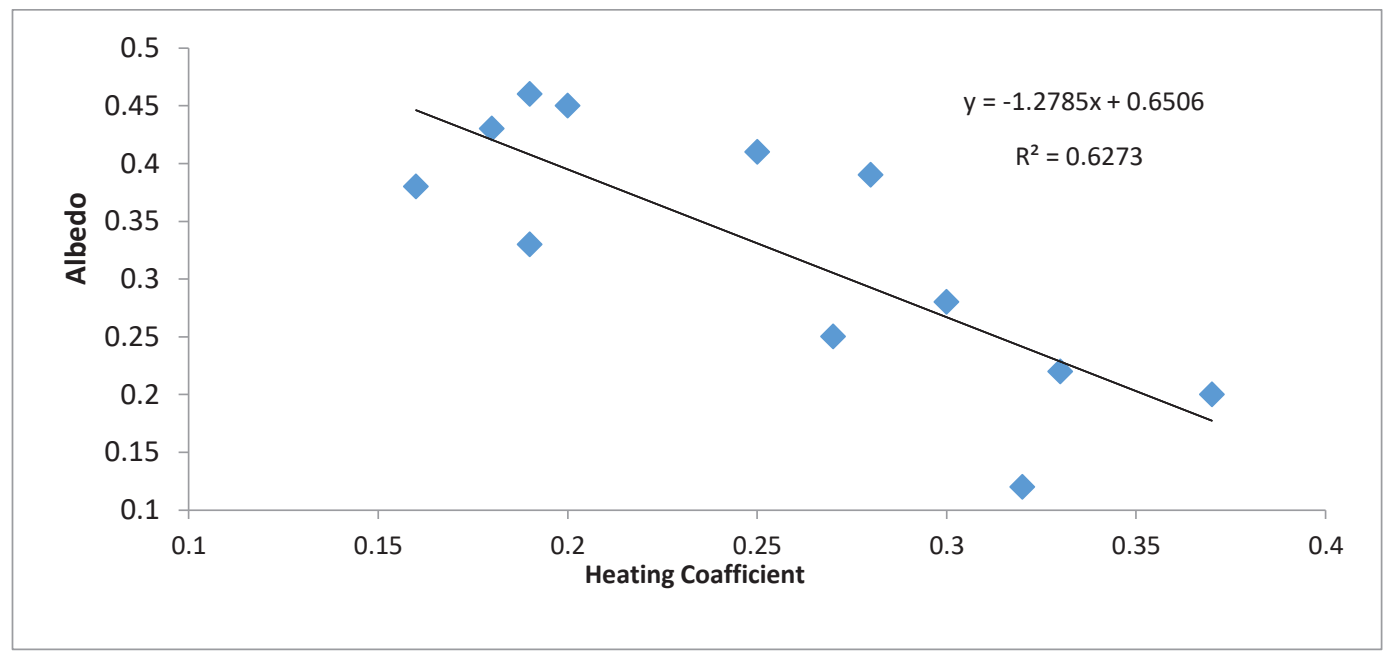

Fig. 7: Relationship between albedo and heating coefficient values.

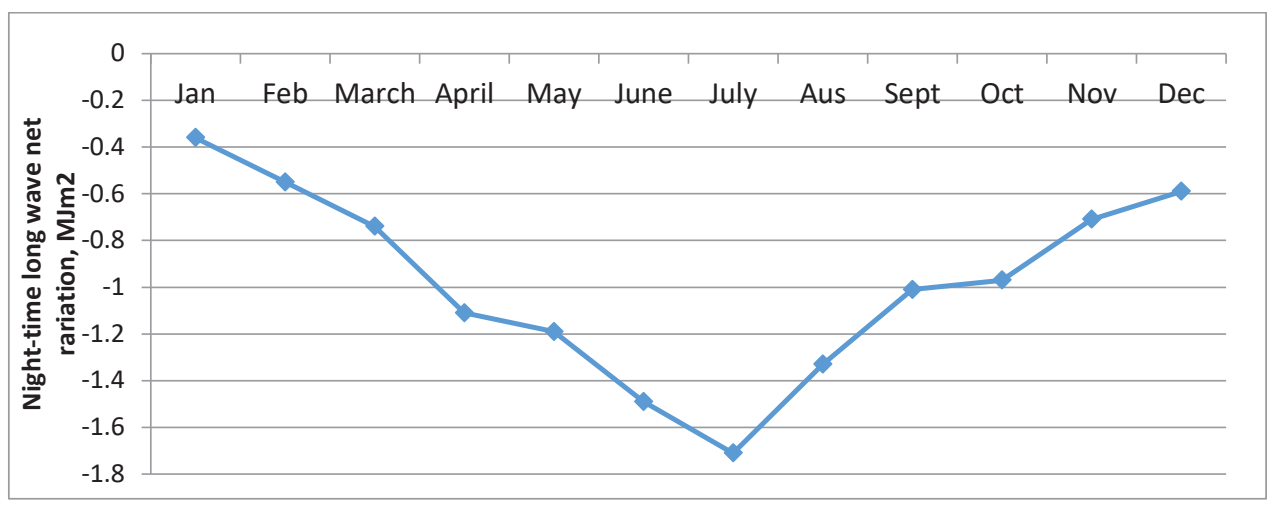

Fig. 8: Monthly mean night-time net longwave radiation.

\section{CONCLUSIONS}

Based on the outcomes of the analysis of historical climatic information in the Baghdad region for the study period, considerable alternations have taken place in Iraq. Annual CDD and HDD have reduced, while the annual mean of ambient temperature and annual solar radiation have increased.

Building surface materials, light colours and external cladding are the main factors affecting heat absorbance and transmittance. Consequently, air passing over the surface becomes cooler, especially at sunset. Since most buildings are exposed to solar radiation, it is, therefore, essential to design for human comfort based on the climatic context of a building. Sustainability in building and urban design strategies should be the focus of architects and engineers in arid climates. The relationship between local climatic conditions such as airflow and building position, orientation and shading must be considered in its connection to the consequent human comfort and integrity.

\section{ACKNOWLEDGEMENTS}

The authors would like to thank the Institute for Urban and Regional Planning, University of Baghdad for their funding and support of this project.

\section{REFERENCES}

Akbari, H., Menon, S. and Rosenfeld, A. 2009. Global cooling: Increasing worldwide urban albedos to offset $\mathrm{CO}_{2}$. Climatic Change, 94: 275-286.

Al-Ansari, N. A., Ezz-Aldeen, M., Knutsson, S. and Zakaria, S. 2013. Water harvesting and reservoir optimization in selected areas of South Sinjar Mountain, Iraq. Journal of Hydrologic Engineering, 18: 1607-1616.

Al-Ansari, N. 2013. Management of water resources in Iraq: Perspectives and prognoses. Engineering, 5(8): 667-684.

Al-Ansari, N.A., Ali, A. and Knutsson, S. 2014. Present conditions and 
future challenges of water resources problems in Iraq. Journal of Water Resource and Protection, 6: 1066-1098.

Al-Ansari, N. A., Abdellatiff, M., Zakaria, S., Mustafa, Y. T. and Knutsson, S. 2014. Future prospects for macro rainwater harvesting (RWH) technique in North East Iraq. Journal of Water Resource and Protection, 6: 403-420.

Al-Waeely, A. A., Salman, S. D., Abdol-Reza, W. K., Chaichan, M. T ., Kazem, H. A. and Al-Jibori, S. H. 2014. Evaluation of the spatial distribution of shared electrical generators and their environmental effects at Al-Sader City-Baghdad-Iraq. International Journal of Engineering \& Technology IJET-IJENS, 14(2): 16-23.

Al-Maamary, H. M. S., Kazem, H. A. and Chaichan, M. T. 2017. Climate Change: the game changer in the GCC region. Renewable and Sustainable Energy Review, 76: 555-576.

Al-Waeli, A., Al-Asadi, K. and Fazleena, M. 2017. The impact of Iraq climate condition on the use of solar energy applications in Iraq: a review. International Journal of Science and Engineering Investigations, 6(68): 64-73.

Bretz, S., Akbari, H. and Rosenfeld, A. 1998. Practical issues for using solar-reflective materials to mitigate urban heat islands. Atmospheric Environment, 32(1): 95-101.

Butera, F. M. 2014. Sustainable building design for tropical climate principles and applications for Eastern Africa. United Nations Human Settlements Programme, (UN-Habitat).

Bonafoni, S., Baldinelli, G. and Rotili, A. 2017. Albedo and surface temperature relation in urban areas: analysis with different sensors. Urban Remote Sensing Event (JURSE). Joint, Dubai, United Arab Emirates.

Chapin, F. S., Sturm, M., Serreze, M. C., McFadden, J. P., Key, J. R., Lloyd, A. H., McGuire, A. D., Rupp, T. S., Stan, H., Hpfstede, G. and Kalma, J. D. 1966. Radiation balance of natural conditions. Q.J. R. Meteorological Soc., 92: 128-140.

Cofaigh, E. O., Johan, A. and Lewis, J. O. 1996. The Climate Dwelling: An Introduction To Climate Responsive Residential. James \& James Ltd., 35-38.

Chen, Y. H., Li, X. B. and Xie, F. 2001. Study on surface albedo distribution over Northwest China using remote sensing technique (in Chinese). Scientia Geographica Sinica, 21(4): 327-333.

Encyclopedia Britannica 2009. Online.Tigris-Euphrates River System: Physical Features, available at: http ://www.britannica.com/eb/article-9110543/Tigris-Euphrates-riversystem

ESA 2017. United 22Nations Department of Economic and Social Affairs.). Population Division. Retrieved 10 September, 2017.

Fanack, A. 2018. Chronicle of the Middle East \& North Africa. accessed, March. https://fanack.com/iraq/geography/

Hui, S. C. and Cheung, K. P. 1997. Multi-year (MY) building simulation: Is it useful and practical? In: Proc. of the IBPSA Building Simulation Conference. Prague, Czech.

Hasson, A., Alaskari, A. and Jweeg, M. 2013. Energy balance on soil-tree canopy system through urban heat island mitigation. International Journal of Enhanced Research in Science and Technology, 2(1).

Hasson, A., Kubba, A. E., Kubba, A. I. and Hall, G. 2017. Heat balance and its effect on building types. journal of Civil Construction and Environmental Engineering, 2(1): 7-11.

Huld, T., Paietta, E., Zangheri, P. and Pascua, I. P. 2018. Assembling typical meteorological year data sets for building energy performance using reanalysis and satellite-based data. Atmosphere, 9(53): 1-22.

King, W. C., Eugene, J., West, P. P. N., Anderson, P. J., Cowher, D. D.,
Dalton, J. B., Gloede, J. S., Herl, B. K., Lahood, A., Lohman, A. D., Mangin, P. E., Malinowski, J. C., Palka, E. J., Pannell, R. P., Sampson, M. R. and Thompson, W. C. 2003. A Geography. Department of Geography \& Environmental Engineering United States Military Academy Jon C Malinowski, USA.

Lam, J. C. 1995. Degree-day climate parameters for Hong Kong. International Journal of Ambient Energy, 16: 209-18.

Langston, G . and Ding, K. 2001. Sustainable Practices in the Built Environment. $1^{\text {st }}$ ed., Routledge Publishing, UK.

Li, G. P. and Xiao, J. 2007. Diurnal variation of surface albedo and relationship between surface albedo and meteorological factors on the western Qinghai-Tibet Plateau. Scientia Geographica Sinica, 27(1): 63-67.

Muir, J. 2009. Iraq Marshes Face Grave New Threat. BBC News, 24 February, http://news.bbc.co.uk/2/hi/middle_east/7906512.stm .

Nste, N., Adhujari, R. S., Delpero, C., Leonforte, F. and Timis, I. 2017. Sustainable building design in Kenya. The 8th International Conference on Applied Energy-ICAE2016., Energy Procedia, 105: 2803-2810.

Omer, T. M. A. 2011. Eroding Soils and Expanding Deserts, Country Pasture/ Forage Resource Profile. FAO, Iraq.

Osman, Y., AL-Ansari, A., Abdellatif, M., Aljawad, S. and Knutsson, S. 2014. Expected future precipitation in central Iraq Using LARS-WG stochastic weather generator. Scientific Research Publishing Inc., 948-959.

Pike, P. 1994. Weather Data, Building Services Research and Information Association, Berkshire, England.

Prelgauskas, E. 2003. Arid climates and enhanced natural ventilation. Environment design guide, DES 20. Australian Institute of Architects, Melbourne.

Roaf, S. and Bairstow, A. 2008. The Oxford conference: a re-evaluation of education in architecture. WIT Press, Southampton., UK.

Rashid, H. A. 2014. Microclimatic Factors Effect on Productivity of Construction Industry. Open Journal of Civil Engineering, 173-180.

Rashid, H. A. 2014. Model tool for predicting of outdoor air temperatures on construction materials manufacture performance in Baghdad. ARPN Journal of Engineering and Applied Sciences, 9(7).

Schaaf, C. B., Cihlar, J., Belward, A ., Dutton, E. and Verstraete, M. 2009. Albedo and reflectance anisotropy in ECV-T8. GTOS Assessment of the Status of the Development of Standards for the Terrestrial Essential Climate Variables, 26-27, Rome, Italy.

Torrance, V. B. 1991. Buildings as climate modifiers. Energy and Buildings, 16 (3-4): 907-913.

USAID 2010. Climate Change Risk Profile: Iraq. United States Agency for International Development, USA.

Waro, H. and Mwasha, A. 2013. The impact of sustainable building envelope design on building sustainability using Integrated Performance Model. International Journal of Sustainable Built Environment, 2(2): 153-171.

Yang, H. and Lu, L. 2004. Study of typical meteorological years and their effect on building. American Society of Heating, Refrigerating and Air Conditioning Engineers. ASHRAE Transactions, 110(2): 424-431.

Zhang, C. C., Wang, X. Y. and Cui, Y. L. 2005. A study of the ground surface parameters in the Yellow River Delta using remote sensing data. Hydrology and Engineering Geology, 2: 71-75.

Zakaria, S., Al-Ansari, N. and Knutsson, S. 2013. Historical and future climatic change scenarios for temperature and rainfall for Iraq. Journal of Civil Engineering and Architecture, 7(12): 1574-1594.

Zareaian, S. and Zadeh, K. A. 2013. The role of climate factors on designing and constructing buildings (from urbanization architecture approach). Bulletin of Environment. Pharmacology and Life Sciences, 3: 197-200. 